\title{
Ecological Assessment of Water Quality of Betwa River in Jhansi District
}

\author{
D.M. Tripathi ${ }^{1}$ and S. Tripathi ${ }^{2 *}$ \\ ${ }^{1}$ Deptt. Of Microbiology Bundelkhand University, Jhansi \\ ${ }^{2}$ Deptt. Of Environmental Science Bundelkhand University, Jhansi \\ Email: smritienvs@gmail.com
}

\begin{abstract}
Jhansi is situated in Central part of India in Bundelkhand region of Uttar Pradesh, India. Betwa is the main river in Jhansi which is also a tributary of river Yamuna. The present investigation was carried out on Betwa River for the assessment of water quality. The sampling locations were chosen carefully in order to get maximum representation of the diverse ecohydrological environment within the river system. The water samples were analyzed for various physicochemical and microbial parameters such as pH, EC, TSS, TS,TDS, total hardness, Ca, Mg , alkalinity, acidity, $\mathrm{Cl}$, DO, BOD, free $\mathrm{CO}_{2}$, temperature and MPN. Results showed that the water of Betwa River is alkaline in nature with higher concentration of cations. Nitrates, phosphates and heavy metals are significant in the water which can be attributed due to high rate of decomposition and anthropogenic pressure. Higher BOD, COD, Turbidity and low DO level in water is due to abundance of animated life and the microbial activity, which results in the depletion of the dissolved oxygen.
\end{abstract}

Keywords: River, heavy metal, pollution, water quality.

\section{Introduction}

Water is a wondrous gift of nature and Rivers play a major role in assimilating or carrying industrial and municipal waste water, manure discharge and runoff water from agricultural field, road ways and streets which are responsible for river pollution (Ward and Elliot, 1995). Rivers play a major role in controlling the global water cycle and in the hydrologic cycle they are the most dynamic agents of transport (Dalai, T.K., et al 2004).

The addition of various kinds of pollutants and nutrients through the agency e.g. municipal sewage, industrial effluents, agricultural runoff into the water bodies brings about a series of changes in the physicochemical and characteristics of water, which have been the subject of several investigations (Tripathi et al., 2011). Deterioration in the water quality is now a global problem. Discharge of toxic chemicals, over pumping of aquifer and contamination of water bodies with substance that promote algae growth are some of the today's major causes for water quality degradation (Pandey et al., 2014). Water with metals in discharges from mining, smelting and industrial manufacturing, is a long-standing phenomenon (Tripathi et al., 2011). Almost $70 \%$ of the surface and ground water in India has become polluted due to the discharge of domestic sewage and industrial effluents in to natural water resources such as rivers, streams, lakes (Sangu and Sharma,1987). Thus, estimation of quality of water is extremely important for proper assessment of the associated hazards (Warhate et al., 2006). In societies like our India with developing economics, the optimum development, efficient utilization and effective management of their water resources should be the dominant strategy for economic growth. But in recent years unscientific management and use of this resources for various purpose almost invariably has created undesirable problems in its wake, water logging and salinity in the case of agriculture use and environment pollution of various limits as a result of mining, industries and municipal use (Kumar et al., 2008).

Bundelkhand region in U.P. is the semi-arid zone and considered as the dry zone by Govt. of U.P. Jhansi is a well-known district of Bundelkhand region of Uttar Pradesh with a geographical area of 502.75 thousand hectare. Betwa is the main river in Jhansi which is also a tributary of river Yamuna. The total length of river from the origin to its confluence with Yamuna in $590 \mathrm{~km}$ out of which $232 \mathrm{~km}$ 
lies in MP \& the balance $358 \mathrm{~km}$ in Jhansi, Uttar Pradesh. Rapid increase in industries, mining sites, industrial discharge, domestic sewage, dumping of solid waste and unplanned urbanization impose a serious threat on the water bodies in Jhansi. Pollution in groundwater and surface water created health problems (Raja et al., 2010). The quality of surface water is generally under a considerable potential of contamination especially by agriculture pesticides dumping of biomedical waste, mining and industrial waste.

No proper and adequate work has been done on the river Betwa from origin to end in the Jhansi city. Therefore, we conducted between upstream \& downstream of Betwa River in Jhansi the monitoring of river water quality with duration of time.

\section{Paper Preparation}

\subsection{Study Area}

Jhansi is located in the plateau of central Indian area dominated by rocky reliefs and minerals underneath the soil. The study area lies in southwest portion of Uttar Pradesh state in India between $25^{\circ} 30^{\prime}$ and $25^{\circ} 57^{\prime} \mathrm{N}$ latitude and $78^{\circ} 40^{\prime}$ and79 $25^{\prime} \mathrm{E}$ longitudes. Being on a rocky plateau, Jhansi experiences extreme temperatures. Winter begins in October with the retreat of the Southwest Monsoon (Jhansi does not experience any rainfall from the Northeast Monsoon) and peaks in mid-December. Water is extremely essential for survival of all living organisms.

\subsection{Sampling and Analysis}

Sampling of water samples was done manually on fortnightly basis from January to June 2015 and transferred to the laboratory, preserved and stored for further analytical determinations and treatment. Biological activity such as microbial respiration, chemical activity such as precipitation or $\mathrm{pH}$ change, and physical activity such as aeration or high temperature must be kept to a minimum. Methods of preservation include cooling, $\mathrm{pH}$ control, and chemical addition. The length of time that a constituent in ground water will remain stable is related to the character of the constituent and the preservation method used (Environmental Protection Agency 1982; APHA-AWWA-WEF, 2005). Samples were analyzed for $\mathrm{pH}$, electrical conductivity (EC), Total dissolve solid (TDS), Hardness, total alkalinity, sulphate $\left(\mathrm{SO}_{4}^{-2}\right)$, chloride $\left(\mathrm{Cl}^{-}\right)$and fluoride $\left(\mathrm{F}^{-}\right)$using standard method (APHA, 2005). For data accuracy, reagent blanks and standards were analyzed at beginning and end of the measurement. For analytical precision, the samples were analyzed in triplicates. The reproducibility was within $\pm 5 \%$ in all measurements.

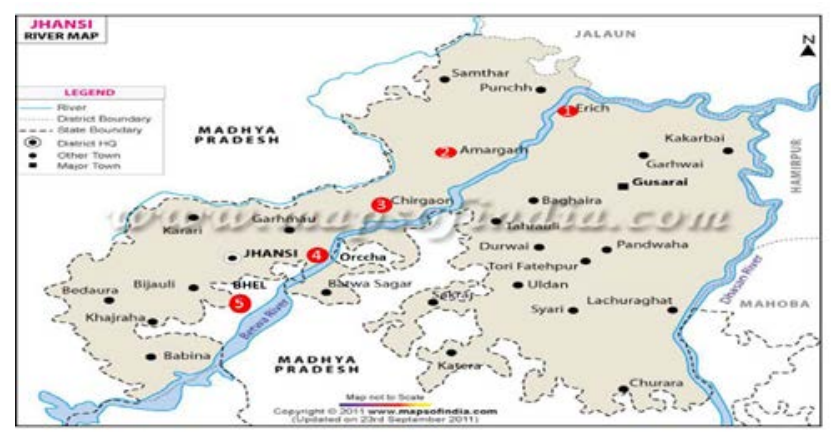

Figure 1. Map of Jhansi District showing five sampling stations in River Betwa

\subsection{Statistical Analysis}

Multivariate analyses were performed through hierarchical agglomerative CA and PCA. After standardization of the data (z-score transformation), CA was performed on all the six stations by single linkage method using Euclidean distance as a measure of similarity. PCA was performed to obtain 
significant principal components (PCs) from the data of wastewater from all the stations and groups obtained from CA with a view to assess spatial differences in ground water quality. All the statistical and mathematical calculations were conducted using SPSS 16 software.

\section{$3 \quad$ Result and Discussion}

\subsection{General Description of River Water}

The descriptive statistics of physical and chemical parameters analyzed in the water samples collected from different study site are given in Table 1.Results revealed that $\mathrm{pH}$ value ranged slightly acidic in all the sampling stations $(6.17-6.95)$. The $\mathrm{EC}$ and $\mathrm{pH}$ of this soil samples are within the permissible limits (WHO, 1984). The $\mathrm{pH}$ values in the present study ranged from5.4 to 6.99. The highest value (6.99) was recorded in Orccha in the month of February and the lowest values were recorded in Chirgaon in the month of February. The higher values may be due to attributed sewage discharged by surrounding city and agricultural fields. Soni and Visavadia (2013)also noticed the higher values of $\mathrm{pH}$ in winter period in Narmada River, M.P.The higher values may be due to attributed sewage discharged by surrounding city and agricultural fields. The minimum and maximum value of conductivity is $100 \mu \mathrm{S} / \mathrm{cm}$ in month of

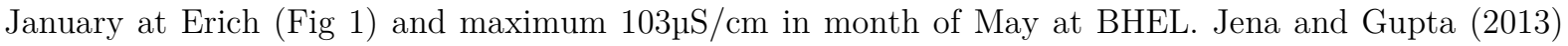
reported that high conductivity in the summer indicates the mixing of sewerage in river water as these sites are located near populated towns.

The presence or absence of the free carbon dioxide in surface water is mostly governed by its utilization by algae during photosynthesis and also through its diffusion from air (Landgeet al, 2013). Carbon dioxide combines chemically with water to form carbonic acid which affects the $\mathrm{pH}$ of the water. Carbonic acid dissociated partly to produced hydrogen and bicarbonates ions. The bicarbonates ions decompose further forming more hydrogen and carbonates ions. The highest average value of free carbon dioxide was recorded at site Orccha $(37.4 \mathrm{mg} / \mathrm{l})$ and lowest value recorded at site BHEL $(7.92 \mathrm{mg} / \mathrm{l})$.

Total hardness is a parameter of water quality used to describe the effect of dissolved minerals (Ca and $\mathrm{Mg}$ ), determining solubility of water for domestic, industrial and drinking purpose attributed to presence of bicarbonates, sulphate, chloride and nitrates of calcium and Magnesium (Taylor, 1949). High concentration of chlorides is considered to be the indicator of pollution due to organic wastes of animal or industrial origin. Chlorides are troublesome in irrigation water and also harmful to aquatic life (Raj Kumar et al.,2004). Chloride that dissolves easily in water is toxic to most aquatic organisms because it reacts quickly with other substances in water (Padmanabha and Belagali, 2001). Visavadia and Soni (2013), also noticed that The high amount of chloride is an indication of burgeoning anthropogenic pressure on water bodies. Minimum dissolved oxygen due to effluents discharge, as suggested by Emongoret al. (2005), and Agarwal and Saxena (2011), that the industries were releasing some organic substances that were of high oxygen demanding wastes.

Low content of dissolved Oxygen assign of organic pollution, is also due to inorganic reductants like Hydrogen sulphide, Ammonia, Nitrates, Ferrous ions and other such oxidisable substances ( Ara et al. , 2003). In the present study the minimum and maximum value of BOD is $100 \mathrm{mg} / \mathrm{l}$ at the site Amarghar in the month of May and maximum value of $240 \mathrm{mg} / \mathrm{l}$ at the site of Chirgaon in the month of May. High concentration of BOD is due to heavy sediments, organic matter and industrial pollutants added in during rainy days. Water quality of Machnariver deteriorates due to mixing of untreated sewage which increases the concentration of BOD, which was found in the range of $123-166 \mathrm{mg} / \mathrm{l}$. Nitrate is the most highly oxidized and usually the most abundant form of combined inorganic nitrogen in surface water bodies. The concentration of nitrate contained in fresh water seems to be increased by agricultural waste and sewage contamination. During the present investigation an increased concentration of Nitratenitrogen was observed in downstream of the rivers. Such increase may be due to rapid decomposition of organic matter (Kumar and Pal, 2010; Sharma, 2003; Shyamalaet al., 2008). It also emphasized that when the dead organic matter decomposes in water, it forms complex proteins which get converted into nitrogenous organic matter and finally to nitrate by bacterial activity.

Turbidity is commonly linked to total suspended solids (TSS) because water with high TSS levels typically looks murkier and has higher turbidity measurements. Common suspended solids are clay, silt, 
and sand from soils, phytoplankton (suspendedalgae), bits of decaying vegetation, industrial wastes and sewage.

Table 1. Water quality of Betwa river at different sampling stations

\begin{tabular}{c|c|c|c|c|c}
\hline \multirow{2}{*}{ Parameters } & \multicolumn{5}{|c}{ Sites } \\
\cline { 2 - 6 } & Erich & Amargarh & Chirgaon & Orccha & BHEL \\
\hline $\mathrm{pH}$ & 6.17 & 6.34 & 6.168 & 6.944 & 6.95 \\
\hline $\mathrm{Ec}$ & 101.67 & 101 & 100.8 & 100.8 & 101.2 \\
\hline Temp & 18.26 & 18.52 & 18.48 & 16.74 & 17.68 \\
\hline Free $\mathrm{CO}_{2}$ & 32.23 & 28.16 & 23.76 & 37.4 & 7.92 \\
\hline Acidity & 13.33 & 8 & 12.8 & 15.2 & 30 \\
\hline Alkalinity & 320 & 236 & 284 & 1000 & 1992 \\
\hline Hardness & 46.6 & 56 & 44 & 88 & 68 \\
\hline Chloride & 21.3 & 9.94 & 18.46 & 63.9 & 13.49 \\
\hline Calcium & 76.61 & 50 & 38 & 22 & 48 \\
\hline magnesium & 23.3 & 13 & 26 & 70 & 10 \\
\hline DO & 7.7 & 6.76 & 6.68 & 7.96 & 4.32 \\
\hline BOD & 18.6 & 15 & 17.2 & 8.6 & 13 \\
\hline TDS & 253.3 & 288 & 278 & 324 & 314 \\
\hline TSS & 43.3 & 42 & 36 & 44 & 56 \\
\hline TS & 296.6 & 330 & 314 & 368 & 354 \\
\hline
\end{tabular}

\subsection{Pattern Recognition of Ground Water}

Principal component analysis was also done on 15 variables at 5 sites in two seasons. An Eigen value gives a measure of significance of the factor. The factors with higher values are significant. The factor analysis generates 3 components. An eigenvalue gives a measure of the significance of the factor: the factors with the highest eigenvalues are the most significant. Eigenvalues of 1.0 or greater are considered significant (Shrestha and Kazama, 2007). Classification of factor loading is thus 'strong', 'moderate' and 'weak', corresponding to absolute loading values of $>0.75,0.75-0.50$ and 0.50-0.30, respectively (Liu et al., 2003). These factors and rotated factor components are given and the factor scores are mapped out in figure 2 which demonstrate the scree plot and score plot. These three factors explain $97.46 \%$ of the variance. Score plot provides 3 components including 5 sites and all parameters. The significant positive $(\mathrm{p}<0.05)$ correlated parameters were demonstrated in component 1 (PC1), significant negatively $(\mathrm{p}<0.05)$ correlated parameters were indicated in component $2(\mathrm{PC} 2)$. Slightly positive $(\mathrm{p}>0.05)$ and negatively correlated $(\mathrm{p}>0.05)$ parameters were shown in component 3 (PC3).

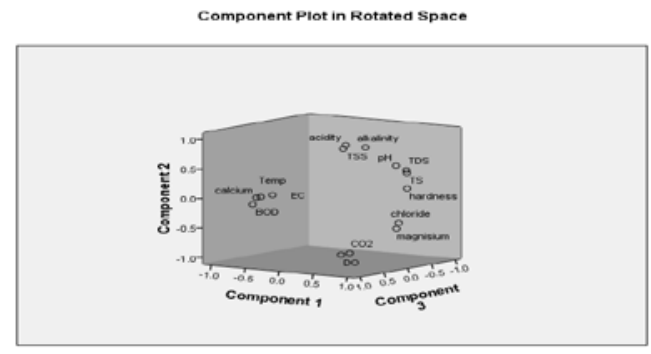

Figure.2: PCA loading plot 


\section{Conclusions}

The present study revealed that the surface water is the main source of water in Jhansi i.e. Betwa River is the source of surface water. Both the quality and quantity of this resource should be maintained for betterment of the local people. Before management of water bodies the physico-chemical characteristics of the water should be thoroughly studied. The temperature of all sites was found to be progressive with the advancement of summer season. With the increase in temperature of air there was automatically corresponding increase in temperature of water. The BHEL site for the river water analysis indicates more pollutant in comparison with other sites. Results also revealed that higher human activities, mining, urbanization and human encroachment put higher pressure on surface water. After investigation it has been concluded that that river Betwa is unpolluted up stream while as downstream it is polluted and the main source of pollution is the sewage disposal and agricultural runoff from the catchments areas and needs proper treatment before uses.

\section{References}

1. Agrawal, A., Saxena, M. (2011) Assessment of pollution by physicochemical water parameter using regression analysis: A case study of Ganga River at Moradabad, India. Adv. Appl. Sci. Res. 2(2):185-189.

2. Ara, S.,Khan,M.A. andZagarM.Y.,(2003) Physico-chemical characteristics of Dal lake water. In : Kumar(Ed.) Aqu.Env.Toxicol.,Daya Publishing House, Delhi, 128-134.

3. Dalai T. K., Krishnaswami S. and Sarin M.M.(2002) Major ion chemistry in the headwaters of the Yamuna river system: chemical weathering, its temperature dependence and $\mathrm{CO} 2$ consumption in the Himalaya; GeochimCosmochimActa,66 3397-3416.

4. Emongor, V., Kealotswe, E., Koorapetse, I., Sankwasa, S. and Keikanetswe S., (2005) Pollution indicators in Gaberone effluent, J. Appl. Sci., 51, pp 47-150.

5. Kumar, J. and Pal, A. (2010). Water Quality of Two Century old Freshwater Pond of Orai, Jalaun district BundelkhandRegion, U.P., India, Recent Res. Sci. Technol. 2(2): $34-37$.

6. Kumar, J., Singh, S. and Pal, A.(2008). Water quality of Turamdih and Jaduguda uranium mines and adjacent areas,East Singhbhum, Jharkhand, J. Ecophysiol. Occup. Hlth. $8:$ 7-14.

7. Liu, C. W., Lin, K. H., Kuo, Y. M., (2003) Application of factor analysis in the assessment ofgroundwater quality in a Blackfoot disease area in Taiwan. Sci. Total Environ., 313 (1-3):77-89.

8. Padmanabha, B., Belagali, S.L., (2007) Water quality index of Kabiniriver in the kallahally village of Nanjangud Taluka of Mysore District, Karnataka. J. Environ. Sci. Eng. 49(1):48-50.

9. Pandey, P.K., Kass, P.H., Soupir, M.L., Biswas, S., Singh, V.P. (2014) Contamination of water resources by pathogenic bacteria. AMB Express, 4:51.

10.Raj Kumar, S.,Velmurugan, P., Shanti, K., Ayyasamy, P.M. and Lakshmanaperumalasamy, P.(2004) Capital Publishing Company, lake 2004,pp.339-246.

11.Raja R.E., Lydia S., Princy M., andChritopher G. (2002) Physico-Chemical Analysis of SomeGroundwater Samples of KotputliTown Jaipur, Rajasthan. Indian JEnviron Prot. 22(2): 137.

12.Sangu, R.P.S, Sharma S.K.(1987). An assessment of water quality of river Ganga at Garmukeshwar. Ind. J. Ecol 14(20): 278-287.

13.Sharma, S. (2003) Agricultural Use of Sewage waters in Gwalior: Ionic Quality Assessment, Indian J. Environ.Hlth., 4(40) : 343-348.

14.Shrestha S, Kazama F. (2007) Assessment of surface water quality using multivariate statistical techniques: Acase study of the Fuji river basin, Japan. Environmental Modelling \& Software, 22(4): 464-475.

15.Shyamala, G., Shivananad, K. P. and Babu, S. S. (2008) A Preliminary report on the physico chemical nature of waterpollution in and around Erode own, Tamil Nadu. Natl. Environ. Pollu. Technol., 7(3): 555-559.

16.Tripathi S, Pathak V, Tripathi DM, Tripathi BD. (2011) Application of ozone based treatments of secondary effluents. Bioresour. Technol.102:2481-2486.

17.Ward A.D., Elliot W.J., (1995) Environmental Hydrology. Lewis Publishers. Boca Radittaton, Florida.

18.Warhate, S.R., Yenkie, M.K.N., Chaudhari,M.D., Pokale, W.K. (2006) Impacts ofmining activities on water and soil. J.Environ. Sci. Eng., 48(2): 8188. 